\title{
Larry Hightower, our colleague, mentor, traveling companion, and friend
}

\author{
R. William Currie ${ }^{1} \cdot$ Helen Neumann ${ }^{2}$
}

Accepted: 1 February 2021 / Published online: 16 February 2021

(C) Cell Stress Society International 2021

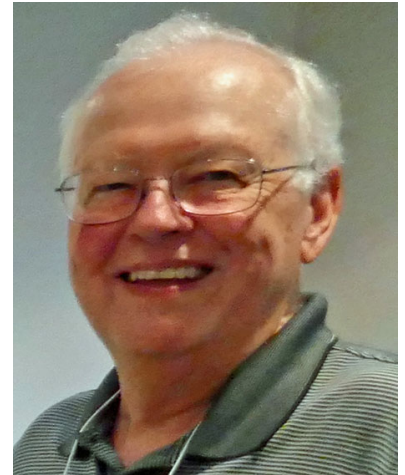

Lawrence E. Hightower

I first met Larry Hightower in 1985 at the second Heat Shock meeting at Cold Spring Harbor Laboratory. I had listened to his talk the day before and was bold enough to introduce myself. We chatted as if he knew my work. I certainly knew his work. In 1980-1982, I was a post-doctoral fellow in the laboratory of Fredric P. White at Memorial University of Newfoundland. Fred and Larry were collaborators and had published a paper entitled "Cellular Responses to Stress: Comparison of a Family of 71-73 Kilodalton Proteins Rapidly Synthesized in Rat Tissue Slices and CanavanineTreated Cells in Culture" (Hightower and White 1981). Of course, now we know that these rapidly synthesized proteins

R. William Currie

William.Currie@Dal.Ca

Helen Neumann

helen.neumann@uconn.edu

1 Department of Medical Neuroscience, Dalhousie University, Box 15000, Halifax, Nova Scotia B3H 4R2, Canada

2 Cell Stress Society International, Inc., University of Connecticut, Storrs, CT, USA are the major inducible proteins of the HSP70 family of heat shock proteins.

Several of Hightower's early papers are the foundation for many studies into the heat shock response. As early as 1973, he was infecting chick embryo cells with Newcastle disease virus. Virus-infected cells generally suppressed protein synthesis while one protein peak at $66 \mathrm{kDa}$ was noticeably increased (Hightower and Bratt 1974). Using chick embryo cells, Hightower (1980) showed again increased synthesis of specific proteins after stimulation with canavanine, the amino acid analog of arginine. These specific proteins with increased synthesis after Newcastle disease virus infection or canavanine treatment were soon identified as stress-induced proteins or heat shock proteins (Hightower and White 1981; Collins and Hightower 1982).

Larry Hightower started his education in stress and stress responses in 1969 when he was drafted into the US Army and completed a tour in Vietnam. He received a $\mathrm{PhD}$ from Harvard University in 1974 and 1 year later was on faculty in the Department of Biology, University of Connecticut. Through the 1980s, 1990s, and 2000s, we were often at the same meetings and in fact traveled together several times to Australia, Argentina, and China. In 1989, Larry discovered the active extracellular release of heat shock proteins from mammalian cells (Hightower and Guidon Jr 1989), and in 1996, he was the driving force behind the formation and publication of this Journal. For 25 years (1996-2020), Hightower has been the Founding Editor-in-Chief of Cell Stress and Chaperones, the leading specialty Integrative Journal of Stress Biology, Medicine, and the Environment, published since 2008 in partnership with Springer Nature.

In 1997, Larry Hightower was elected Fellow of the American Association for the Advancement of Science for his pioneering work on cellular stress responses including the heat stress responses of desert fish. In 1998, he was presented the University of Connecticut Board of Trustees Outstanding Achievement Award. In 2000, he became the Founding President of the Cell Stress Society International. 
Larry retired from the University of Connecticut in 2007 as Professor and Associate Head of the Department of Molecular and Cell Biology and is now Professor Emeritus. His recent research involves the application of hyperbaric oxygen therapy to type 2 diabetes and other metabolic diseases (Verma et al. 2015). In 2017, Dr. Hightower was awarded the CSSI Medallion for Career Achievement in Turku, Finland, at the CSSI Congress.

Larry Hightower has been my good friend for 35 years and I have learned a great deal from him. He is a mentor and role model to many of us in the Cell Stress Society International, Inc. With this writing and on behalf of all our authors and members, reviewers, and Senior Editors, I thank Larry publicly for his many years of service to our Journal and Society.

\section{A note from Helen Neumann}

I worked with Larry from the first days of Cell Stress and Chaperones, starting on a part-time basis and little expecting that Cell Stress and Chaperones, and later the Cell Stress Society International, would rapidly become so important and meaningful in my life.

For the last 15 years, I shared an office with Larry so that in addition to our work on the journal and the society, we got to know each other's students and, in several cases, shared a mentoring role. Larry was the best of professors, loved and respected by his students whose futures he fostered so generously.

Larry applied the same caring attitude to his work as Editor-in-Chief. His vision and determination saved Cell Stress and Chaperones at a time when the Journal's future seemed uncertain. His integrity, respect, and support for his colleagues, authors, and reviewers have made the Journal what it is today. Larry treated everyone with the same quiet courtesy, always looking for ways to support and encourage, and always looking for ways to make things better. How many times did I hear "I've been thinking, Helen, what do you think about..." and he would propose something marvelous. He has been the brains behind the Journal and the Society. We all relied on him and he never let us down. Being the Founding Editor-in-Chief of CSC has been a labor of love for Larry and it has been my great fortune to have shared the work with him. Happily, Larry will remain part of the editorial office as our Publishing Editor and will continue to steer the Journal and the CSSI into the future.

With kind regards, and thank you, Helen Neumann and R. William Currie

\section{References}

Collins PL, Hightower LE (1982) Newcastle disease virus stimulates the cellular accumulation of stress (heat shock) mRNAs and proteins. $\mathrm{J}$ Virol. 44:703-707. https://doi.org/10.1128/JVI.44.2.703-707.1982

Hightower LE (1980) Cultured animal cells exposed to amino acid analogues or puromycin rapidly synthesize several polypeptides. J Cell Physiol 102:407-427. https://doi.org/10.1002/jcp.1041020315

Hightower LE, Bratt MA (1974) Protein synthesis in Newcastle disease virus-infected chicken embryo cells. J Virol 13:788-800. https://doi. org/10.1128/JVI.13.4.788-800.1974

Hightower LE, Guidon PT Jr (1989) Selective release from cultured mammalian cells of heat-shock (stress) proteins that resemble gliaaxon transfer proteins. J Cell Physiol. 138:257-266. https://doi.org/ 10.1002/jcp.1041380206

Hightower LE, White FP (1981) Cellular responses to stress: comparison of a family of 71-73-kilodalton proteins rapidly synthesized in rat tissue slices and canavanine-treated cells in culture. J Cell Physiol 108:261-275. https://doi.org/10.1002/jcp.1041080216

Verma R, Chopra A, Giardina C, Sabbisetti V, Smyth JA, Hightower LE, Perdrizet GA (2015) Hyperbaric oxygen therapy (HBOT) suppresses biomarkers of cell stress and kidney injury in diabetic mice. Cell Stress Chaperones 20:495-505. https://doi.org/10.1007/ s12192-015-0574-3 Epub 2015 Feb 4

Publisher's note Springer Nature remains neutral with regard to jurisdictional claims in published maps and institutional affiliations. 